SHS Web of Conferences 24, 02014 (2016)

DOI: $10.1051 /$ shsconf/20162402014

(c) Owned by the authors, published by EDP Sciences, 2016

\title{
Chinese ethnomusicology to explore fieldwork methods
}

\author{
Lihan Fan* \\ Music and Dance Department, Sichuan Minzu College, Kangding, Sichuan, China
}

\begin{abstract}
The main working approach and scope of the national musicians is the field investigation. The exploration of successful experience of the Chinese national music in the fieldwork is very necessary to effectively organize, carry out and complete the fieldwork of the Chinese music. This paper which is combined with the summary of experience, expert consultation and literature reading tries to verify and promote the effective fieldwork method through field investigation, so as to avoid that the national musicians with curiosity give a hurried and cursory glance at the destination and miss the first-hand resources in the field investigation due to lack of effective working approach, which plays a positive role in the inheritance and development of the Chinese national music.
\end{abstract}

Keywords: national music; fieldwork; approach

\section{INTRODUCTION}

Chinese national music mentioned herein is proposed relative to the traditional western music system. Compared with Chinese folk music, it is more generalized. Each minority in our county is closely linked, but it also retains its own unique culture. These cultures are manifested through various channels. Its musical phenomenon is one of the most common ways to express unique national culture. With the efforts of predecessors, the research of Chinese national music has demonstrated a lot of excellent materials, and also summed up a lot of effective experience and ways for us to continue to explore. Faced with the national music culture under the new situation, we could not stand still. However, what should we understand? How to understand?

The best way is to step into the background of the music culture, and go deep into the field to experience music. When we are in these places with a unique culture, we integrate the music into ourselves, and even personally experience the process of music creation, in order to maximize the experience of the nature of the local music. This mode of understanding the nature is different from the personal thinking model and subjective model drawn from experience [4], which is more memorable, with more diverse perspectives.

*Corresponding author: 12803356@qq.com
Fieldwork is the first step into the national music ${ }^{[7]}$ When we are in different places, we listen to, feel and experience the national music at the initial contact; transcribe, record and analyze the information in the field; reflect, describe and interpret the music and social status. Only with effective fieldwork methods, can we successfully complete the above process, generate new knowledge in this process, and improve all aspects of the Chinese national music culture.

\section{PSYCHOLOGICAL PREPARATION OF FIELDWORK}

In the fieldwork, the fieldworkers shall prepare for the forthcoming research, just go for a walk, look and listen, rather than simply relying on a curious mind, so the fieldworkers complete a period of journey. Some fieldworkers complete their fieldwork as a reporter after consulting several questions and recordings. The fieldworkers should be the outsiders of the local culture ${ }^{[5]}$, who should understand music through experience and feeling under the leadership of local insiders as much as possible, without a need to translate the local folk music. The properties of the national music researchers are somewhat different in front of different research objects. Generally speaking, the outsiders or insiders of the local culture ${ }^{[10]}$ adopt the concept of "national methodology": do research through in-depth 
thought and mode of activity of the social organization (the concept named by Garfinkel in 1967), and try to fully explore from multiple perspectives, so as to avoid focusing on a nation as much as possible.

For the local folk customs, folk music and national culture, as an outsider, it is impossible to understand the music of insiders no matter how hard, because the insider understands the music relying on the interactions of other content related to the life. The cultural understanding of the members of society is certainly different from that of the outsiders who are aware of the culture. Faced with this fact, the outsiders need not feel depressed in the fieldwork, because we do not emphasize on understanding from the same way of the insider, but find out meaningful aspects that are not observed by the insiders from the perspective of the outsider. The outsiders and insiders can research the same kind of music culture from different aspects, and make their different contributions.

A lot of unique musical phenomena generate due to the changes of the national culture. For example, some nations protect and inherit the music relying on the oral or mental instructions. Many fieldworkers go deep into it with a sense of rescue mission, but lack of respect for the local music. Such prejudice may disappoint the local people, and affect the provision of materials. We should clearly understand that the world is not comprised of many communities that are easy to be distinguished. Each community does not have its own unique culture, because each community does not exist alone. Even for the relatively remote and isolated villages, they belong to an entirety coexistent with this community, with an interaction. With different perspectives on observing the music, there will be different results of distinction. However, the national music and folk music does not change due to different definitions. Therefore, there is no need for the fieldworkers to always emphasize on the culture alterity of the research object, but the fieldworkers should carry out multi-perspective comparative research, and state the nature of various music cultures as much as possible [8].

These psychological preparations are beneficial to the smooth development of the field work. The beforehand research of the research object and preparation of doubts is also a chance of reflection. To enter the field with doubts and upright attitude, and feel the culture through contacts with the local people and music experience, such fieldwork experience is possible to bring back valuable results.

\section{RESEARCH OBJECTIVES OF FIELDWORK}

When people are engaged in the fieldwork, they are full of curiosity and doubts in people and things that they first come into contact. At this time, they might as well calm down and listen to the story of insiders, or broaden their understandings of the local music and culture.

In June 2011, I entered into Dawu County, Ganzi Prefecture with a Tibetan music culture research team, and visited some local temples, inheritors and art museums, and recorded some folk songs, mountain songs and interviews. At that time, I did not have any clear targets for what to understand and how to understand, so these recordings have been stored up. In the fieldwork, my deepest feeling was the last afternoon of the journey, and a few team members spontaneously came to a vast prairie. When I laid in the soft green grassplot to bathe in the sunshine and breathed the cold plateau air, a few eagles circled around in the vast blue sky from time to time. When I placed myself in this scene, I involuntarily recalled a song called as a melody of Tibetan songs that I listened to a few days ago. At that time, this cappella song was sung by a girl with a loud and clear voice. The melody of song is fresh and natural, and the mellow voice is just apt to vast and remote Tibetan prairie in June. When I came back to the studio, I recorded this song as a music score. And when I talked about this song with others, I would naturally think of prairie scenery felt in that afternoon.

My personal example above is a negative example. I fail to live up to the materials provided by the respondents due to this random access. We need to bring questions to make investigation, but the course of investigation is not just to record as an onlooker, and exclude ourselves. We need to participate in the local culture after entering into an area. In my failure experience, I obtained some recordings, but I could not feel the cultural background delivered by singers and narrators. Except for an old Tibetan song, listening to other recordings again could not reproduce the local music cultural atmosphere.

With the course of China's rural construction and development, urban culture increasingly penetrates into the rural areas, and there are fewer and fewer in-depth researches on the fields and pastoral areas. Once we are in the fieldwork state of a kind of culture, we need to be correlated with the research subjects. The respondents generally narrate the relevant personal experience in the event of answering questions of the research. Sometimes, these narrations are not systematical explanations expected by the implementer of the research, but we may have intuitional feelings on the research subjects by sharing the narrations of the respondents. These feelings are stored in the consciousness through the course of the researcher's fieldwork. To experience the music as life, it will not only increase work experience, but it is also an experience in life. Thinking deeply the interaction of these experiences can broaden the understanding of the music for the national musicologist, and sort out more comprehensive and intensive conclusions.

The mysterious music culture is prone to attract scholars. Many researchers embrace the mentality of exploration, and they are lack of knowledge and un- 
derstanding of the cultural background, and ignore the acceptance level of the researcher's participation in the mysterious culture, and the acceptance level of the outside world. The presence of every kind of culture has its own course of development. Some contents of these cultures are unwilling to be disturbed by the outside world, and even some of contents are hidden deliberately, which may be the fundamental to explain the mysterious culture. To inquire into these fundamentals based on the research of the culture, the outsiders have a feeling of cultural aggression. To disclose these fundamentals, the insiders also have a feeling of cultural defection. Therefore, they should make preparations before fieldwork. As the survey deepens, in case of hidden content, giving up at this time embodies the respect and understanding of the culture surveyed.

Faced with the music culture that we could not search for origins, we are lack of a powerful interpretation, so we can only archive and save them. Currently, there are many ways of archiving, especially wide application of the computer and self-media. In the long run, the shelf life of the electronic media is relatively long, and it is convenient and feasible to save the classified recordings, videotapes, photographs and other firsthand resources in a dedicated hard disk drive of the computer. The naming of the data must be scientific, systematic, concise and convenient-to-query. Under the conditional premise, paper documents can also be formed and saved as classified files after the formation of a certain scale. Compared with the electronic save, paper document is properly saved, and its content is not prone to be tampered and lost. If a series of continuous concern is given to a kind of national music phenomenon, the constant change of the society and the development direction of the art form can be observed from archives after a long-term accumulation of the arts collection materials. These changes reflect the impact of the social change on the art of music. With the accumulation of the amount, we may summarize the definition of some theories.

Bruno Nettl, an academician of American Academy of Arts and Sciences (Bruno Nettl, born in 1930) mentioned in his book Research of Ethnomusicology: 29 topics and concepts: Among a variety of factors of the music culture, the change of the music itself is the slowest; the behavioral change is faster; the change of music concept is the fastest. Therefore, sampling, recording and saving a certain national music fieldwork at present is improvement and supplement of the entire music system. Saving and maintaining the data of the national music culture at present stage provides preconditions for further reaching rules and conclusions.
4 FIELD SURVEY [9] AND INDIGENOUS RESEARCH OF CHINESE NATIONAL MUSIC

In 1949, China's first special music research institution, the Music Research Institute of the Academy of Arts was founded in Tianjin. Under the leadership of Yang Yinliu, Li Yuanqing and other academic leaders, many scholars have been engaged in a series of investigations of the national music since the 1950s, which was an epoch-making act, and accumulated the initial practical experience for the research of China's national music, and summarized the core of these experiences and research methods: field survey and indigenous research methods for the national folk songs and dances. Under the currently cultural background, this core is not plain and outdated, but it is a very weak link in the research of the current national music in a certain sense ${ }^{[6]}$

The research of Chinese folk music has experienced a long period of formation and development in the $20^{\text {th }}$ century. So far, we have had a certain scale in the excavation, protection and research of the folk music, and many excellent works of folk songs and dances. With the course of the social development and rural urbanization and the evolution of humanistic values, it seems that we do not have effective ways to inherit and protect folk songs and dances.

Since the 1980s, China's music education has been dominated by the western music system, and gradually formed a mainstream form. For a number of musicologists who grow up from the western music system, how to apply the specialized knowledge to the research of Chinese national music? When we are devoted to the folk songs and dances and music culture, we are confused how to apply, combine and transform the vast theoretical knowledge we have learned, especially on the basis of the western music system. Comprehensively considering the researches of the domestic and foreign national music, and analyzing a lot of successful experience, we clearly know that, only adhering to the tradition of the ethnic study, can we select appropriate research methods from numerous research methodologies, and maintain the pure lineage of indigenous research as much as possible. We need to refer to the theoretical system of western music, develop suitable research tools and excavate brilliant treasures of our national music, so our research achievement will not be replaced or changed according to the changing circumstances.

Some areas of China's ethnic minority have a relatively remote and isolated geographical environment, so the humanistic environment and its forms of songs and dances have a unique style. However, with the continuous development of culture and tourism, the musical works of the minority are increasingly symbolic and formal. After analysis, the causes of this phenomenon are closely related to unfulfilled field survey and indigenous research of the songs and dances of some minorities. However, the causes of 


\section{SHS Web of Conferences}

these problems are related to unfamiliarity with the local environment, language barriers, differences of living habit, understanding and acceptance of the local culture and many other factors of the non-native folk music researchers.

For the location of the national music culture, the working methods of the field survey are used for the empirical research, which can be better to protect the inherit folk songs and dances in minority, and avoid damage and misunderstanding in the development process as much as possible, so as to provide relatively true and objective sampling methods for the creation of music pieces with the materials of the local folk music, and also provide relatively systematic, standardized and scientific music field research means for the musicologists with the research object of Chinese folk songs and dances.

Take a certain national music in Chinese national music as an example. With the research objects of the fieldwork methods, a similar method which is combined with the ethnology, ethnosociology, ethnomusicology, comparative musicology and other specialized knowledge can be worked out by comparing with the fieldwork methods and achievements of several nations.

This method can be roughly divided into four stages. The first stage focuses on the summarization of practical experience is to collect related investigations on the basis of the existing survey researches for analysis and summarization of experience, and present the current status quo.

The second stage focuses on the problem analysis is to do a comprehensive analysis which is combinee with the relevant theoretical knowledge and cultural background and clarify the reasons of work fault, low efficiency and other situations caused in the working methods according to the status quo presented at the first stage.

The third stage is the proposal of approach. It is to extend the research at the previous two stages, deepen further exploration, and apply the literature review, expert interview, folk visit or other research ways to find solutions.

The fourth stage is the practical verification. It is to revisit the location of the national music, especially where there is a problem at the first stage, and apply the solutions proposed at the third stage to solve the problems and errors.

The fourth stage is the key and difficult point in the whole method. The basis of the practice and practical verification are required by proposing the fieldwork methods of the national music. In practice, there is a need to survey the changes of the result by comparing with different research methods, and analyze the reasons of failure or defect in the fieldwork, and form experience towards the next research.

\section{POST FIELDWORK STAGE}

To archive, classify, store and share resources within a certain range is a fine summary and further promotion of the fieldwork, which can also transform its work experience to the research achievements. The transformation of the fieldwork achievements of the national music mainly has two forms: One is to interpret the national music in different places; the other is to arrange the fieldwork as texts. The previous field experience is significantly important in the interpretation of the national music. The experience of listening to the music pays more attention to the entirety of music and its culture and folk custom. And the experience of playing a musical instrument gives consideration to the entirety of music and its details and the expression of style and characteristics. When the player is filled with the folk music, various intuitive feelings of the fieldwork will be collided with each other so that the national music can be vividly conveyed from the hilltops and the field to the concert hall, thus presenting the style of the national music from another perspective combined with the folk melody and understanding of the player.

To transform to the texts, the fieldwork participants should first have an objective manner and reach an objective to truly understand the style of the local national music culture by the readers who browse the arts collection data. The author has several suggestions on writing the texts for discussion: do not conjecture the history and origin from the status quo, but respect the status quo of the existing national music; do not be too cumbersome in written narration of the music culture, but add intuitive picture and audio, thus playing a better display effect; do not easily criticize a certain musical and cultural phenomenon, nor randomly attach these music cultures with their own subjective definitions, thus producing a great impact on others' judgments; do not treat different national music cultures with a uniform scale, because the background of feeling the culture is different. Music is a diverse culture, so there are also a variety of different scales for judgment and appreciation of the music.

Compared with the national borders, music has a closer relationship between different nations. Several neighboring countries are alike in terms of the music. For instance, a kind of music style with the fierce syncopation and distinctive percussion instrument is unique in Xinjiang region of China and the neighboring areas in Central Asia and South Asia. Thus, in the fieldwork, the research of the music creation focuses on the understanding and experience of the music culture, without a need to make a clear boundary between the countries and nations. This research integrates the fieldwork with culture, attaches importance to the exchange between the researcher and local people, generates empirical knowledge and finally links up with the national music researchers as much as possible, thus making efforts for construction of a 
SSHE 2015

complete map of world music.

The valuable resources of the national music excavated by the fieldwork can also be combined with the development and application, and present the national arts collection on the modern stage, thus moving towards a broader range of audience and making an important supplement to the world music culture.

\section{ACKNOWLEDGEMENT}

This paper is financially supported by the Educational Reform Project of the State Ethnic Affairs Commission in 2013-Phased Achievements about the Research on the Curriculum Reform of Musicology and Inheritance of National Music of Institutes in the Western Regions (GN: 13090) and the Humanities and Social Sciences General Project of the Education Commission of Sichuan Province in 2014-Phased Achievements about the Research on the Modern Transformation and Inheritance of the Minority Music in Garze Tibetan Autonomous Prefecture based on the Perspective of Cultural Industry (GN: 14SB0264).

\section{REFERENCES}

[1] Qiao Jianzhong. 2010. Thirty Years' Papers of the Institute for Traditional Music in China (Volume II in 19802010). Shanghai: Shanghai Music Publishing House.

[2] Wu Guodong. 2012. Introduction to Ethnomusicology. Beijing: People's Music Publishing House.

[3] Beverly Diamond \& Pirkko Moisala. 2012. Music and Social Gender. Shanghai: Shanghai Conservatory of Music Publishing House.

[4] Jeff Titon. 2012. Fieldwork Exploration. Western Ethnomusicology of the World of Music. Shanghai. Shanghai Conservatory of Music Publishing House.

[5] Bruno Nettl. 2012. Research of Ethnomusicology. Shanghai: Shanghai Conservatory of Music Publishing House.

[6] Zhang Yu. 2012. Exploration of Local Method on Fieldwork of Chinese Traditional Music. Beijing. China Conservatory of Music.

[7] Du Yaxiong. 1985. Methods and procedures of arts collection work. Journal of Central Conservatory of Music.

[8] Xiang Yang \& Lv Qiwei. 2005. Alienation of arts collection concept. Chinese Music.

[9] Tan Zhi. 2013. On arts collection and fieldwork - speaking from arts collection or fieldwork. People's Music.

[10] Xue Yibing. 2010. Chinese thought on ethnomusicological fieldwork. Music Art. 